\title{
PENGARUH INVESTASI PADA INDUSTRI KECIL FORMAL DAN PADA INDUSTRI KECIL NON FORMAL TERHADAP SUATU PRODUK DOMESTIK REGIONAL BRUTO DI KABUPATEN ACEH UTARA
}

\author{
Dr. Ratna*, Devri Sandi Hutabarat ${ }^{\mathrm{a}^{*}}$ \\ ${ }^{a}$ Fakultas Ekonomi dan Bisnis Universitas Malikussaleh \\ *Corresponding author: *Ratna@unimal.ac.id
}

$\overline{\text { A R T ICLE }}$ A B S T R A C T

\begin{tabular}{|c|c|c|}
\hline Keywords: & Formal Small & Industry \\
\hline Investment, & $\begin{array}{l}\text { Non-Formal } \\
\text { and Gross }\end{array}$ & $\begin{array}{r}\text { Small } \\
\text { Regional }\end{array}$ \\
\hline Domestic Pr & oduct & \\
\hline
\end{tabular}

1.

\section{PENDAHULUAN}

Pembangunan ekonomi adalah masalah yang penting dalam perekonomian suatu negara yang sudah menjadi agenda setiap tahunnya. Tujuan utama pembangunan ekonomi selain berupaya untuk menciptakan pertumbuhan yang setinggi-tingginya, pembangunan harus pula berupaya untuk menghapus atau mengurangi tingkat kemisikinan, ketimpangan pendapatan dan tingkat pengangguran atau upaya menciptakan kesempatan kerja bagi penduduk sebab dengan kesempatan kerja masyarakat akan memperoleh pendapatan untuk memenuhi kebutuhan hidupnya Todaro dalam (Wiwoho, 2018).

Pertumbuhan perekonomian daerah secara umum dapat dilihat dari indikator perkembangan Produk Domestik Regional Bruto (PDRB). Produk Domestik Regonal Bruto (PDRB) di bedakan menjadi dua yaitu Atas Dasat Harga Berlaku (ADHB) dan Atas Dasar Harga Konstan (ADHK). PDRB atas dasar harga berlaku masih dipengaruhi oleh kenaikan harga barang dan jasa, sehingga tidak terlalu akurat untuk mengukur tingkat pertumbuhan ekonomi. Salah satu syarat utama bagi perkembangan Produk Domestik Regional Bruto (PDRB) adalah kriteria investasi, dimana tujuan utama dari investasi adalah untuk memperoleh manfaat yang layak di kemudian hari, apabila kegiatan investasi meningkat, maka kegiatan ekonomi pun ikut meningkat (Wiwoho, 2018).Pembangunan industri di Kabupaten Aceh Utara tidak terpisahkan dari arah pembangunan industri wilayah yang harus mampu mengikuti sekaligus memenuhi tuntutan pembangunan regional dan nasional tanpa mengabaikan kebutuhan spesifik wilayah. Keragaman fisik wilayah dalam beberapa kondisi merupakan kendala, namun disisi lain merupakan potensi sebagai pendorong laju pembangunan industri wilayah. Kejelian dan kecermatan kelompok perencana dan pelaksanaan pembangunan industri dalam memanfaatkan potensi dan mengatasi kendala merupakan salah satu kunci keberhasilan perindustrian (Aulia, 2018).

Peranan sector industri dalam meningkatkan pertumbuhan ekonomi berupa output sektor industri atau PDRB sektor industri tidak terlepas dari adanya peranan investasi dan tenaga kerja. Investasi yang dilakukan adalah investasi langsung berupa investasi domestik (penanaman modal dalam negeri) dan investasi asing (penanaman modal asing). Investasi langsung dapat menyerap banyak tenaga kerja yang berada dipasar tenaga kerja dan investasi langsung juga diharapkan dapat meningkatkan pertumbuhan ekonomi. Hal ini terjadi karena output yang dihasilkan akan semakin meningkat seiring dengan meningkatnya investasi di daerah (Aulia, 2018).

Investasi dilakukan untuk membentuk faktor produksi kapital, dimana sebagian dari investasi tersebut digunakan untuk pengadaan berbagai barang modal yang akan digunakan untuk kegiatan proses produksi. Melalui investasi proses produksi dapat ditingkatkan yang kemudian mampu akan meningkatkan output produksi sehingga akan menaikan pendapatan daerah. Iklim investasi mencerminkan sejumlah faktor yang berkaitan dengan lokasi tertentu yang membentuk kesempatan dan insentif bagi perusahaanperusahaan untuk melakukan investasi secara produktif dan menciptakan lapangan pekerjaan (Aulia, 2018).

Keberhasilan pertumbuhan ekonomi tidak dapat dipisahkan dari meningkatnya investasi (Silalahi, 2012). Investasi adalah kata kunci penentu laju pertumbuhan ekonomi, karena disamping akan mendorong kenaikan output secara signifikan, juga secara otomatis akan meningkatkan permintaan input, sehingga pada gilirannya 
akan meningkatkan kesempatan kerja dan kesejahteraan masyarakat sebagai konsekuensi dari meningkatnya pendapatan yang diterima masyarakat. Investasi adalah mobilisasi sumber daya untuk menciptakan atau menambah kapasitas produksi/pendapatan dimasa yang akan datang. Gambaran perkembangan pembangunan daerah tidak lepas dari distribusi dan alokasi investasi antar daerah (Silalahi, 2012).Investasi antar daerah dalam kaitannya tidak perlu dipisahkan investasi dari pihak swasta ataupun pemerintah, mengingat faktor-faktor yang menentukan lokasi kedua jenis investasi tersebut tidak selalu sama. Pada umumnya kedua jenisinvestasi tersebut akan dapat menambah kesempatan kerja dan mengatasi masalah-masalah ekonomi dan sosial seperti kemiskinan, pengangguran dan sebagainya.

Kabupaten Aceh Utara terkenal sebagai salah kawasan industri besar yang ada di Provinsi Aceh, hal ini disebabkan karena kejayaan pada masa lampau dengan berdirinya perusahaan Pupuk Iskandar Muda (PIM), Pupuk ASEAN Aceh Fertilizer (AAF), PT. Exxon Mobile, dan PT. Arun. Namun seiring berjalannya waktu hingga saat ini Aceh Utara hanya menyisakan PT. PIM, dan Exxon Mobile (Sekarang Pertamina Hulu Energi). Aceh Utara juga merupakan pusat industri kecil. jumlah unit usaha industri kecil formal dan non formal di Kabupaten Aceh Utara pada tahun 2016 sejumlah 2.082 unit usaha yang terdiri dari 1.736 unit usaha non formal dan 346 unit usaha formal.Jenis Industri Makanan, Minuman dan Tembakau memiliki persentase kontribusi terbesar dalam penyerapan tenaga kerja dan omset industry dengan persentase sebesar 27,96 persen dan 20,83 persen. Sebanyak 29,88 persen dari jumlah unit usaha di Kabupaten Aceh Utara bergerak pada jenis industri tersebut, untuk meningkatkan pertumbuhan ekonomi perlu adanya peningkatan investasi agar produksinya meningkat dan nantinya akan meningkatkan pendapatan daerah. Supaya lebih jelasnya dapat dilihat pada tabel dibawah ini :

Tabel 1

Produk Domestik Regional Bruto, Investasi Industri Kecil Formal dan Investasi Industri Kecil Non Formal di Kabupaten Aceh UtaraTahun 2010-2016

\begin{tabular}{|r|r|r|r|}
\hline Tahun & $\begin{array}{c}\text { Produk } \\
\text { Domestik } \\
\text { Regional Bruto } \\
\text { (Ribu Rupiah) }\end{array}$ & $\begin{array}{c}\text { Industri Kecil } \\
\text { Formal } \\
\text { (Ribu Rupiah) }\end{array}$ & $\begin{array}{c}\text { Investasi } \\
\text { Industri Kecil } \\
\text { Non Formal } \\
\text { (Ribu Rupiah) }\end{array}$ \\
\hline 2010 & $9.112 .698,71$ & 3.306 .326 & 949.602 .968 \\
\hline 2011 & $9.795 .872,78$ & 13.590 .245 & 3.856 .149 \\
\hline 2012 & $10.322 .871,48$ & 4908349 & 16.674 .315 \\
\hline 2013 & $10.663 .301,18$ & 4.908 .349 & 16.674 .315 \\
\hline 2014 & $11.108 .760,96$ & 17866191 & 7.607 .551 \\
\hline 2015 & $11.625 .526,42$ & $17,866,191$ & 1.054 .250 \\
\hline 2016 & $12.005 .120,47$ & 33.982 .757 & 6.527 .936 \\
\hline Sumber: (BPS Kabupaten Aceh Utara, 2018)
\end{tabular}

Berdasarkan data yang terdapat pada tabel 1.1 menjelaskan tentang bagaimana keadaan produk domestik regional bruto, investasi industri kecil formal dan investasi industri kecil non formal di Kabupaten Aceh Utara. Pada tahun 2010 Investasi industri kecil formal yaitu sebesar Rp 3.306.326 milyar, investasi industri kecil non formal yaitu sebesar Rp 949.602.968 milyar, dan pada tahun yang sama PDRB yaitu sebesar Rp 9.112.698,71 milyar, pada tahun 2011 investasi industry kecil non formal menurun dari tahun sebelumnya yaitu sebesar Rp 3.856.149 milyar, tetapi PDRB pada tahun yang sama malah meningkat dari tahun sebelumnya yaitu sebesar Rp 9.795.872,78 milyar, seharusnya ketika investasi industri kecil non formal menurun PDRB juga ikut menurun, yang terjadi malah meningkat. ini merupakan permasalahan yang terjadi di Aceh Utara.

Pada tahun 2012 investasi industri kecil formal menurun dari tahun sebelumnya yaitu sebesar Rp 4.908.349 milyar, penurunan investasi ini malah menyebabkan PDRB meningkat dari tahun sebelumnya yaitu sebesar Rp 10.322.871,48 milyar, seharusnya penurunan investasi dapat menurunkan PDRB. Pada tahun 2014 permasalahan yang sama juga di alami oleh investasi industri kecil non formal yang mengalami penurunan dari tahun sebelumnya yaitu sebesar Rp 7.607.551 milyar, akan tetapi PDRB nya malah meningkat dari tahun sebelumnya yaitu sebesar Rp 11.108.760,96 milyar. Kesamaan kejadian permasalahan juga terjadi pada tahun 2015 pada sector investasi industri kecil non formal yang menurun dari tahun sebelumnya yaitu sebesar Rp 1.054.250 milyar, akan tetapi penurunan investasi ini malah menyebabkan peningkatan PDRB yaitu sebesar Rp 11.625.526,42 milyar dari tahun sebelumnya.

\section{LANDASAN TEORI}

\section{Produk Domestik Regional Bruto}

Produk domestik regional bruto menurut (Wardhana, 2011) didefinisikan sebagai jumlah nilai tambah yang dihasilkan oleh seluruh unit usaha dalam suatu wilayah, atau merupakan jumlah seluruh nilai barang dan jasa akhir yang dihasilkan oleh seluruh unit ekonomi di suatu wilayah. PDRB dapat menggambarkan kemampuan suatu daerah mengelola sumber daya alam yang dimilikinya, oleh karena itu, besaran PDRB yang dihasilkan oleh masingmasing daerah sangat bergantung kepada potensi faktorfaktor produksi di daerah tersebut

Menurut Sukirno dalam (Mauliansyah, 2017) pertumbuhan ekonomi adalah kenaikan output perkapita dalam jangka panjang. Tekanannya adalah pada tiga aspek, yaitu: proses, output perkapita, dan jangka panjang. Pertumbuhan ekonomi adalah proses, bukan gambaran ekonomi sesaat. Pembangunan daerah dan pembangunan sektoral perlu selalu dilaksanakan dengan selaras, sehingga pembangunan sektoral yang berlangsung di daerah-daerah, benar-benar dengan potensi dan prioritas daerah.Untuk keseluruhan pembangunan, daerah juga benar-benar merupakan satu kesatuan politik, ekonomi,sosial, budaya dan pertahanan keamanan didalam mewujudkan tujuan nasional.

\section{Investasi Industri Kecil Formal}

Invetasi industri kecil formal merupakan investasi yang dilakukan terhadap perusahaan yang sudah meiliki surat ijin yang jelas (legal), sumber investasi ini sudah beragam baik dari dalam maupun luar negeri. Investasi adalah penanaman modal untuk satu atau lebih aktiva yang dimiliki biasanya berjangka waktu lama dengan harapan mendapatkan keuntungan di masa-masa yang akan datang (Salim, 2008). Teori ekonomi mendifinisikan investasi sebagai pengeluran-pengeluaran untuk membeli barangbarang modal dan peralatan-peralatan produksi dengan tujuan untuk menggantikan dan terutama menambah barangbarang modal dalam perekonomian yang akan digunakan 
untuk memproduksi barang dan jasa di masa yang akan datang. Dengan kata lain, dalam teori ekonomi investasi berarti kegiatan pembelanjaan untuk meningkatkan kapasitas produksi dalam suatu perekonomian (Wiwoho, 2018).

Menurut Saparuddin (2011) investasi meliputi penambahan stok modal atau barang di suatu negara, seperti bangunan peralatan produksi, dan barang-barang inventaris dalam waktu satu tahun, investasi merupakan langkah mengorbankan konsumsi di waktu mendatang. Bagi suatu negara tidak hanya untuk memaksimalkan output, tetapi untuk distribusi pendapatan, pertumbuhan dan kualitas penduduk serta teknologi. Tingkat investasi yang tinggi akan meningkatkan kapasitas produksi dan membuka lapangan kerja baru yang pada akhirnya berujung pada peningkatan PDRB. Adanya investasi juga memungkinkan terjadinya transfer teknologi dan pengetahuan dari negara maju ke nagara berkembang.

\section{Investasi Industri Kecil Non Formal}

Investasi industri kecil non formal ialah investasi yang dilakukan terhadap perusahaan yang belum memiliki surat ijin yang jelas, investasi ini biasanya merupakan investasi pribadi pemilik perusahan. Menurut Mauliansyah (2017) investasi merupakan permintaan barang dan jasa untuk menciptakan atau menambah kapasitas produksi/pendapatan di masa yang akan datang, dalam investasi tercakup dua tujuan utama yaitu untuk mengganti bagian dari penyediaan modal yang rusak (depresiasi) dan tambahan penyediaan modal yang ada (investasi netto), dalam perhitungan pendapatan nasional, pengertian investasi adalah seluruh nilai pembelian para pengusaha atas barangbarang modal dan pembelanjaan untuk mendirikan industri dan pertambahan dalam nilai stok barang perusahaan yang berupa bahan baku, barang dalam proses, dan barang jadi.

\section{Kerangka Pemikiran}

Adapun kerangka konseptual dalam penelitian ini adalah sebagai berikut:

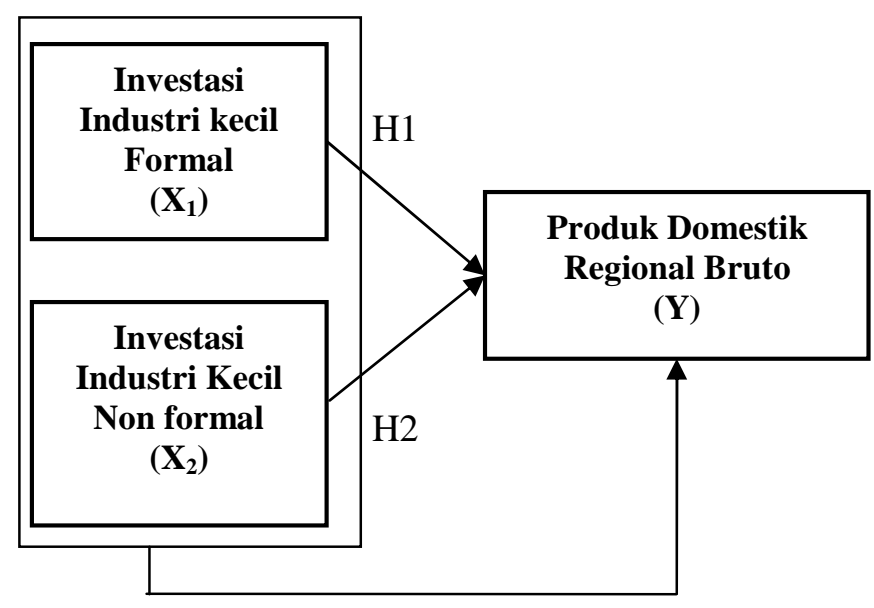

Gambar 1 Kerangka Konseptual

\section{Hipotesis}

Bedasarkan teori, penelitian, dan kerangka berpikir yang telah dipaparkan diatas maka hipotesis dalam penelitian ini adalah :
$\mathrm{H}_{1} \quad$ : Diduga I nvestasi Industri Kecil Formal berpengaruh positif dan signifikanterhadapProduk Domestik Regional Bruto di Kabupaten Aceh Utara.

$\mathrm{H}_{2}$ : Diduga Investasi Industri Kecil Non Formal berpengaruh positif dansignifikan terhadapProduk Domestik Regional Bruto di Kabupaten Aceh Utara.

\section{METODE PENELITIAN}

\section{Data dan Sumber data}

Jenis data yang akan dianalisis dalam penelitian ini adalah data kuantitatif, yaitu data sekunder selama periode 2010-2016 yang diperoleh dari berbagai instansi yang terkait yaitu BPS, BAPPEDA dan sumber-sumber lainnya.Objek penelitian meliputi investasi industri kecil non formal dan investasi industri kecil non formal di Kabupaten Aceh Utara sebagai variabel bebas dan produk domestik regional bruto sebagai variabel terikat. Adapun lokasi penelitian adalah di Kabupaten Aceh Utara.Data yang di gunakan dalam penelitian ini merupakan data sekunder, berupa laporan Aceh Utara dalam angka 2010-2016 yang di dalam data tersebut terdapat produk domestik regional, investasi industri kecil formal, dan investasi industri kecil non formal yang diterbitkan oleh BPS Kabupaten Aceh Utara.

\section{Operasional Variabel}

Variabel yang digunakan dalam penelitian ini terbagi menjadi dua variabel, yaitu variabel dependen atau variabel yang dijelaskan dan variabel independen atau variabel yang menjelaskan. Adapun operasional variabel penelitian ini adalah :

1. Investasi Industri Kecil Formal $\left(\mathrm{X}_{1}\right)$

Investasi industri kecil formalmerupakan investasi yang dilakukan pada industri kecil yang sudah memiliki surat ijin operasi perusahaan, dan biasanya ini ialah invesatasi dalam negeri. Jumlah nilai investasi pada industri kecil formal di Kabupaten Aceh Utara dalam satuan Rupiah.

2. Investasi Industri Kecil Non Formal $\left(\mathrm{X}_{2}\right)$

Investasi industri kecil non formal yaitu investasi yang dilakukan pada industry yang belum memiliki kelangakapan surat ijin atau ijin operasi perusahaan, investasi ini biasanya investasi pribadi pemilik perusahaan di Aceh Utara dalam satuan Rupiah.

3. Produk Domestik Regional Bruto (Y)

PDRB adalah jumlah seluruh balas jasa yang diterima oleh faktor- faktor produksi yang ikut serta dalam proses produksi di suatu wilayah pada periode tertentu. PDRB yaitu tambahan jumlah nilai PDRB selama periode tahun 2010 2016 dalam satuan Rupiah.

\section{Metode Analisis Data}

\section{Analisis Regresi}

Analisis yang digunakan dalam penelitian ini adalah analisis regresi linear berganda yang menggunakan metode OLS (Ordinary Least Square). Dengan 
menggunakan program Eviews 9. Model regresi berganda merupakan suatu model regresi yang terdiri dari satu variable Independen. Bentuk umum regresi linear berganda dapat ditulis sebagai berikut (Salim, 2008):

Keterangan:

$$
Y_{t}=\alpha+\beta_{1} X_{1 t}+\beta_{2} X 2_{t}+e_{t}
$$

Yt = Produk domestikregional bruto

$\alpha \quad=$ Konstanta

$\beta_{1}, \beta_{2}=$ Koefisien Regresi

$\mathrm{X}_{1 \mathrm{t}} \quad=$ Investasi industri kecil formal

$\mathrm{X}_{2 \mathrm{t}} \quad=$ Investasi industri kecil non formal

$\mathrm{e}_{\mathrm{t}}=$ Error term, yaitu tingkat kesalahan dalam penelitianini.

\section{Uji Asumsi Klasik}

\section{Uji Normalitas}

Menurut(Gujarati, 2008) menyebutkan bahwa uji normalitas adalah suatu pengujian dimana jika probabilitasnya lebih besar daripada alpha 5 persen maka uji normalitas diterima. Justifikasi lainnya untuk uji ini adalah dengan membandingkan nilai J-B hitung dengan $\chi 2$ tabel, apabila J-B hitung $<\chi 2$ tabel maka residual terdistribusi normal. Sedangkan menurut (Sunyoto, 2011) Uji normalitas adalah pengujian yang akan menguji data variabel bebas (X) dan data variabel terikat $(\mathrm{Y})$ pada persamaan regresi yang dihasilkan berdistribusi normal atau berdistribusi tidak normal.

Model regresi yang baik merupakan berdistribusi data normal atau mendekati normal. Metode yang sering digunakan untuk melakukan uji normalitas adalah dengan uji Jarque-bera. Jika nilai probabilitasnya lebih besar dari 5\% $(>0,05)$, berarti nilai residual berdistribusi normal. Sebaliknya, jika nilai probabilitas lebih kecil dari 5\% $(<0,05)$, berarti nilai residual berdistribusi tidak normal.

\section{Uji Autokorelasi}

Menurut (Ghozali, 2006)uji autokolerasi bertujuan untuk menguji apakah model regresi linear ada kolerasi antara kesalahan pengganggu pada periode $\mathrm{t}$ dengan kesalahan pengganggu pada periode $\mathrm{t}-1$ (sebelum). Jika terjadi korelasi, maka dinamakan ada masalah autokorelasi. Autokorelasi dapat terjadi karena observasi yang berurutan sepanjang waktu berkaitan satu sama lainnya. Masalah ini timbul karena residual (kesalahan pengggangu) tidak bebas dari runtut waktu (time series) karena gangguan pada seorang individu/kelompok cenderung berpengaruh terhadap individu/kelompok yang sama pada periode berikutnya. Ada beberapa cara yang dapat digunakan untuk melihat terjadi atau tidaknya autokolerasi. Salah satunya denganUjiBreuschGodfrey Serial Correlation LM Test. Dengan ketentuan Obs*R-squareddibandingkan dengan $X^{2}$ dan Probabilitas Chi-Squared sebesar di bandingkan dengan alfa lebibih besar dari5 \% (>0,05).

\section{Uji Multikolinieritas}

Multikolinieritas adalah suatu kondisi dimana terjadinya korelasi yang kuat diantara variabel-variabel bebas (X) yang diikutsertakan dalam pembentukan model regresi linaear(Gujarati,2006). Uji multikolinieritas dilakukan untuk melihat apakah dalam model regresi ditemukan adanya korelasi antar variabel bebas (X). Jika terjadi korelasi yang tinggi, maka model regresi tersebut terjadi multikolinieritas.Untuk mengetahui multikolinieritas dengan menggunakan Eviews dapat dilakukandengan melihat korelasi antar variabel bebas (Correlation Matrix). Jika korelasi antara variabel bebas lebih kecil atau sama dengan $0.8\left(<\_0,8\right)$, berarti tidak terjadi multikolinieritas.

\section{Uji Heteroskedastisitas}

Heteroskedasitas merupakan keadaan dimana varian dari setiap gangguan tidak konstan. Uji heteroskedastisitas dapat dilakukan dengan menggunakan white heteroskedasticity yang tersedia dalam program Eviews. Hasil yang perlu diperhatikan dari uji ini adalah F dan Obs*R-Squared, dengan ketentuan sebagai berikut :

- $\quad$ Bila Obs*R-Squared $>X^{2}$ tabel maka dalam model ini adalah indikasi

Heteroskedastisitas.

- Bila Obs*R-Squared $<\mathrm{X}^{2}$ tabel maka dalam model ini terbebas dari indikasi

Heteroskedastisitas.

\section{Pengujian Hipotesis}

\section{Uji Parsial (Uji-t)}

Menurut (Ghozali, 2006) uji statistik atau uji t pada dasarnya menunjukkan seberapa jauh pengaruh satu variabel independen secara individual dalam menerangkan variabel dependen.Gujarati (2006) uji statistik bertujuan untuk melihat signifikan dari pengaruh variabel bebas secara individual terhadap variabel terikat dengan menganggap variabel bebas lainnya adalah konstan. Hipotesis nol $\left(\mathrm{H}_{0}\right)$ yang akan di uji apakah parameter penelitian ini sama dengan nol, artinya variabel eksplanotari merupsakan penjelas yang signifikan terhadap variabel pendapatan.

1. Jika $t_{\text {hitung }}>t_{\text {tabel, }}$ maka $\mathrm{H}_{1}$ diterima yang artinya variabel penjelas secara individual mempengaruhi variabel yang dijelaskan secara signifikan.

2. Jika $\mathrm{t}_{\text {hitung }}<\mathrm{t}_{\text {tabel, }}$ maka $\mathrm{H}_{1}$ ditolak yang artinya variabel penjelas secara individual tidak mempengaruhi variabel yang dijelaskan secara signifikan

\section{Uji Simultan (Uji-F)}

Untuk menentukan tingkat signifikan secara keseluruhan pada tingkat kepercayaan sebesar 95\%, pengujian hipotesis dengan Uji F. (Gujarati, 2006). Uji F dilakukan dengan membandingkan antara $F_{\text {hitung }}$ dengan $F_{\text {tabel, }}$ apabila $F_{\text {hitung }}>F_{\text {tabel, }}$ maka $\mathrm{H}_{1}$ dan $\mathrm{H}_{2}$ diterima artinya Investasi Industri Kecil Formal (X1) dan Investasi Industri Kecil Non Formal (X2) secara bersama-sama berpengaruh terhadap Produk Domestik Regional Bruto (Y).

\section{Koefisien Korelasi (R)}

Menurut (Supranto, 2009) analisis korelasi merupakan suatu cara untuk mengetahui kuat atau tidaknya hubungan antara variabel independen (X) dan variabel dependen (Y), apabila dinyatakan dengan fungsi linear dan di ukur dengan suatu nilai yang disebut koefisien korelasi. Koefisien korelasi dapat dinyatakan dengan rumus sebagai berikut :

Keterangan :

$$
r=\frac{\mathrm{n}\left(\sum X\right)-\left(\sum X\right)\left(\sum Y\right)}{\sqrt{\left\{n\left(\sum X^{2}\right)-\left(\sum Y\right)^{2}\right\}\left\{n\left(\sum Y^{2}\right)-\left(\sum Y\right)^{2}\right\}}}
$$

$\mathrm{n}=$ Jumlah data

$\mathrm{X}=$ Variabel Independen 
$\mathrm{Y}=$ Variabel Dependen

$\mathrm{r}=$ Koefisien Korelasi

Untuk dapat memberi interprestasi seberapa kuat hubungan itu, maka dapat digunakanpedomen seperti yang tertera pada tabel :

Tabel 2

Tingkat keeratan antara variable bebas dengan variabel terikat

\begin{tabular}{|c|c|}
\hline Nilaikorelasi & Interprestasi \\
\hline $0,000-0,199$ & Sangatrendah \\
\hline $0,200-0,399$ & Rendah \\
\hline $0,400-0,599$ & Sedang \\
\hline $0,600-0,799$ & Kuat \\
\hline $0,800-1,000$ & SangatKuat \\
\hline
\end{tabular}

Sumber : (Sugiono, 2014)

\section{Koefisien Determinasi $\left(\mathbf{R}^{2}\right)$}

Koefisien determinasi ini mengukur seberapa jauh kemampuan model dalam menerangkan variasi variabel dependen (uji goodness of fit). Koefisien ini nilainya antara 0 (nol) sampai dengan 1 (satu). Semakin besar nilai koefisien tersebut maka variabel-variabel independen lebih mampu menjelaskan variasi variabel dependen. Nilai koefisien determinasi merupakan suatu ukuran yang menunjukkan besar sumbangan dari variabel independen terhadap variabel dependen, atau dengan kata lain koefisien determinasi mengukur variasi turunan $\mathrm{Y}$ yang diterangkan oleh pengaruh linier X. Bila nilai koefisien determinasi yang diberi simbolmendekati angka 1, maka variabel independen makin mendekati hubungan dengan variabel dependen, sehingga dapat dikatakan bahwa pengaruh model tersebut dapat dibenarkan (Gujarati, 2009).

\section{HASIL DAN PEMBAHASAN}

\section{Uji Asumsi Klasik}

\section{Uji Normalitas}

Menurut Gujarati (2009) menyebutkan bahwa uji normalitas adalah suatu pengujian dimana jika probabilitasnya lebih besar daripada alpha 5 persen maka uji normalitas diterima. Justifikasi lainnya untuk uji ini adalah dengan membandingkan nilai J-B hitung dengan $\chi^{2}$ tabel, apabila J-B hitung $<\chi^{2}$ tabel maka residual terdistribusi normal. Sedangkan menurut Sunyoto (2011) Uji normalitas adalah pengujian yang akan menguji data variabel bebas (X) dan data variabel terikat (Y) pada persamaan regresi yang dihasilkan berdistribusi normal atau berdistribusi tidak normal. Berikut adalah hasil pengolahan data:

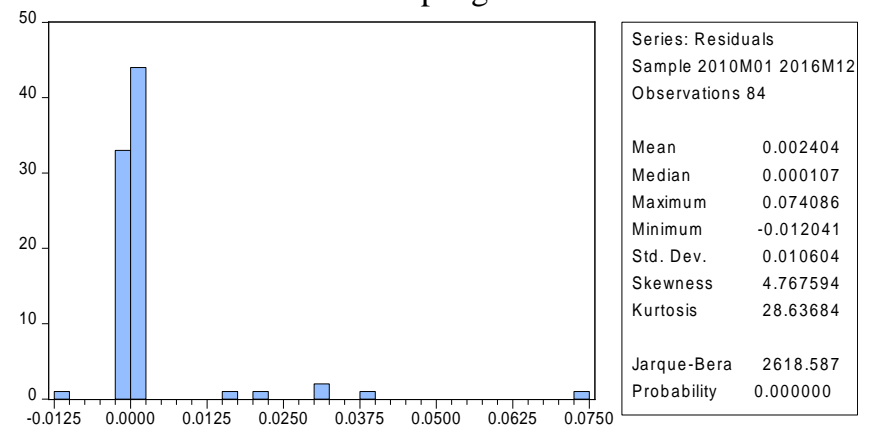

Sumber : Hasil Eviews, data diolah (2019)

Gambar 2 Hasil Uji Normalitas
Berdasarkan hasil pengujian yang tampak pada Tabel di atas nilai Jarque-Bera adalah sebesar 2618.587, sementara nilai Chi Square dengan melihat jumlah variabel bebas yang kita pakai dalam hal ini 2 variabel bebas dan nilai signifikan yang kita pakai dalam hal ini 0,05 (5\%), di dapat nilai Chi Square sebesar 5.99 yang berarti nilai Jarque-Bera lebih kecil dari nilai Chi Square (2618.587 > 5.99) dan Probabilitas sebesar $0,00<0,05$. Artinya investasi industri kecil formal dan investasi industri kecil non formal terhadap produk domestik regional bruto di Kabupaten Aceh Utara, maka dapat disimpulkan bahwa data residual dalam penelitian ini tidak berdistribusi secara normal, karena data tersebut adalah data interpolasi.

\section{Uji Autokolerasi}

Menurut Gujarat dan Porten(2012) uji autokolerasi bertujuan untuk menguji apakah model regresi linear ada kolerasi antara kesalahan pengganggu pada periode $\mathrm{t}$ dengan kesalahan pengganggu pada periode $\mathrm{t}-1$ (sebelum), jika terjadi korelasi, maka dinamakan ada masalah autokorelasi. Autokorelasi dapat terjadi karena observasi yang berurutan sepanjang waktu berkaitan satu sama lainnya. Masalah ini timbul karena residual (kesalahan pengggangu) tidak bebas dari runtut waktu (time series) karena gangguan pada seorang individu/kelompok cenderung berpengaruh terhadap individu/kelompok yang sama pada periode berikutnya. Ada beberapa cara yang dapat digunakan untuk melihat terjadi atau tidaknya autokolerasi. Salah satunya dengan melihat nilai hasil Durbin Watson Stat:

Tabel 3

Hasil Durbin Watson Stat

Durbin-Watson stat

1.980432

Sumber: Hasil Olah Data, 2019

Berdasarkan hasil dari Durbin-Watson stat 1.98 dibandingkan dengan DW tabel $(\mathrm{n}-\mathrm{k})=(84-3)=81$ dengan $\mathrm{DL}=1,56$ dan $\mathrm{DU}=1,72$ nilai tersebut berada diantara 4 $\mathrm{DU}=4-1,72=2,28$ dan 4-DL $=4-1,56=2,44$. Dari hasil ini dapat disimpulkan pada Gambar berikut ini:

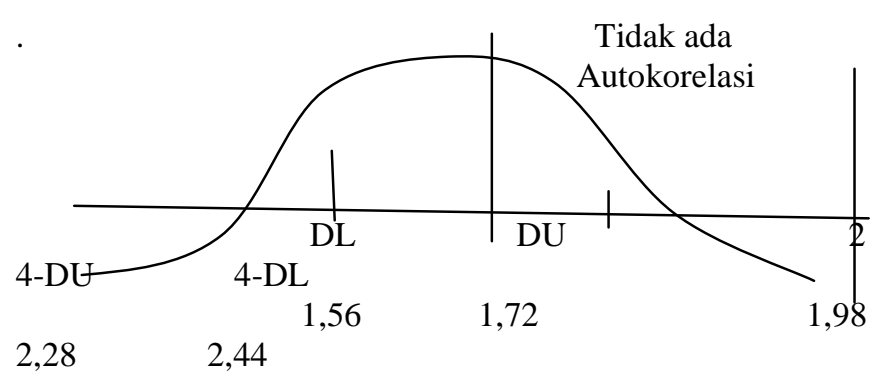

Berdasarkan hasil batas bawah dan batas atas nilai DW dalam model ini sebesar 1,98 sudah terbebas dari indikasi autokorelasi, karena nilai sebesar 1,98 berada pada daerah tidak ada autokorelasi

\section{Uji Heteroskedastisitas}

Heteroskedasitas merupakan keadaan dimana varian dari setiap gangguan tidak konstan. Uji 
heteroskedastisitas dapat dilakukan dengan menggunakan Glejser heteroskedasticity yang tersedia dalam program Eviews 9. Hasil yang perlu diperhatikan dari uji ini adalah $\mathrm{F}$ dan $O b s^{*} R$-Squared, jika nilai probabilitas lebih besar alpha $(0.05)$.

Tabel 4

Hasil Uji Heteroskedastisitas

Heteroskedasticity Test: Glejser

\begin{tabular}{llll}
\hline \hline F-statistic & 0.117555 & Prob. F(2,81) & 0.8892 \\
Obs*R-squared & 0.243112 & Prob. Chi-Square(2) & 0.8855 \\
Scaled explained SS & 0.579372 & Prob. Chi-Square(2) & 0.7485 \\
\hline \hline
\end{tabular}

Sumber: Hasil Olah Data, 2019.

Berdasarkan hasil uji Glejser menggunakan program eviews versi 9, dapatdilihat nilai Obs* $\mathrm{R}$ sebesar dengan $\chi^{2}$ dengan df (2) pada $\chi^{2}$ pada tabel $\alpha: 1 \%$ sebesar 9.21 dan $\alpha: 5 \%$ sebesar 5,99. Berdasarkan hasil Obs*R.squared $0.243<5.99$, Hal ini juga dilihat dari probabilitas sebesar 0.89> 0.05.maka dalam model penelitianini sudah tidak ada indikasi heterosdaktisitas.

\section{Uji Multikolinearitas}

Multikolinieritas adalah suatu kondisi dimana terjadinya korelasi yang kuat diantara variabel-variabel bebas (X) yang diikutsertakan dalam pembentukan model regresi linaear (Gujarati, 2006). Uji multikolinieritas dilakukan untuk melihat apakah dalam model regresi ditemukan adanya korelasi antar variabel bebas (X), jika terjadi korelasi yang tinggi, maka model regresi tersebut terjadi multikolinieritas.

Untuk mengetahui multikolinieritas dengan menggunakan Eviews10 dapat dilakukan dengan melihat korelasi antar variabel bebas (Correlation Matrix), jika korelasi antara variabel bebas kurang atau sama dengan 0.8 $(<0,8)$, berarti tidak terjadi multikolinieritas.

Tabel 5

Hasil Uji Multikolinieritas

\begin{tabular}{|c|c|c|c|}
\hline \multicolumn{2}{|c|}{ Correlation } & & \\
\hline t-Statistic & PDRB & INVFORM & INVNONFORM \\
\hline PDRB & 1.000 .000 & & \\
\hline INVFORM & 0.788946 & 1.000000 & \\
\hline INVNONFORM & -0.676417 & -0.434220 & 1.000000 \\
\hline
\end{tabular}

Sumber: Hasil Olah Data, 2019

Berdasarkan Tabel diatas terlihat bahwa koefisien korelasi antara investasi industri kecil formal dengan PDRB sebesar $0.79<0.8$, untuk koefisien korelasi antara investasi industri kecil non formal dengan PDRB sebesar $0.68<0.8$ sedangkan untuk untuk koefisien korelasi antara investasi industri kecilformal dengan investasi industri kecil non formal sebesar $0.43<0.8 \mathrm{Hal}$ ini menunjukkan tidak terjadinya multikolinieritas pada investasi industri kecil formal dan investasi industri kecil non formal di Kabupaten Aceh Utara.

\section{Hasil uji Regresi Linear Berganda}

Analisis yang digunakan dalam penelitian ini adalah analisis regresi linear berganda yang menggunakan metode OLS (Ordinary Least Square), dengan menggunakan program Eviews 10. Model regresi berganda merupakan suatu model regresi yang terdiri dari satu variabel Independen. Berikut adalah hasil regresi linear berganda yang dilakukan:

Tabel 6

Hasil Uji Regresi Liniear Berganda

\begin{tabular}{lcccc}
\hline \hline \multicolumn{1}{c}{ Variable } & Coefficient & Std. Error & t-Statistic & Prob. \\
\hline \hline $\begin{array}{c}\text { C } \\
\text { LOG(INVFO }\end{array}$ & 16.09837 & 0.135266 & 119.0130 & 0.0000 \\
$\quad$ RM) & 0.011852 & 0.003024 & 3.918995 & 0.0002 \\
$\begin{array}{l}\text { LOG(INVNO } \\
\text { NFORM) }\end{array}$ & -0.006955 & 0.001026 & -6.780714 & 0.0000 \\
$\quad$ AR(1) & 0.993687 & 0.033008 & 30.10447 & 0.0000 \\
SIGMASQ & 0.000117 & $8.04 \mathrm{E}-06$ & 14.53629 & 0.0000 \\
\hline \hline $\begin{array}{l}\text { R-squared } \\
\text { Adjusted R- } \\
\text { squared }\end{array}$ & 0.985393 & Durbin-Watson stat & & 1.980432 \\
$\begin{array}{l}\text { F-statistic } \\
\text { Prob(F- } \\
\text { statistic) }\end{array}$ & 0.984653 & & & \\
\hline \hline
\end{tabular}

Inverted AR

Roots

Sumber: Hasil Olah Data tahun, 2019.

Model dasar penelitian adalah :

$\operatorname{LnYt}=\beta_{0}+\beta_{1} \operatorname{Ln} X_{1 t}+\beta_{2} \operatorname{Ln} X_{2 t}+$ et,

LnPDRBt $=\beta_{0}+\beta_{1}$ LnINVFORM $_{t}+\beta_{2}$ LnINVNONFORM $_{t}+$ et,

Hasilnya adalah :

LnPDRBt $=16.09+0.012 \quad$ LnINVFORM $_{\mathrm{t}}-0.007$ LnINVNONFORM tyaitu dimana :

Konstanta $=16.09$, apabila investasi industri kecil formal dan investasi industrykecil non formal bernilai konstan (tidak ada) maka produk domestik regionalbruto juga akan konstan sebesar16.09. Variabel investasi industri kecil formal sebesar 0.012 adalah apabilainvestasi industri kecil formal meningkat sebesar $1 \%$ maka produk domesik regional bruto akan meningkat sebesar $0.012 \%$, dengan asumsi investasi industri kecil non formal Konstan.Variabel investasi industri kecil non formal sebesar - 0.007 adalah apabila investasi industri kecil non formalmeningkat sebesar $1 \%$, maka produk domestik regional bruto akan menurun sebesar $0.007 \%$, dengan asumsi investasi industri kecil formal konstan.

\section{Pengujian Hipotesis \\ Pengujian Parsial (Uji t)}

Uji statistik merupakan pengujian terhadap koefisien dari variabel bebas secara parsial.Uji ini dilakukan untuk melihat tingkat signifikasi dari variabel bebas secara individu dalam mempengaruhi variasi dari variabel terikat. Pengujian ini dilakukan dengan cara membandingkan $t_{\text {statistik }}$ pada hasil regresi dengan $t_{\text {tabel. }}$ yaitu :

1. Jika $t_{\text {hitung }}>t_{\text {tabel, }}$ maka $\mathrm{H}_{1}$ diterima yang artinya variabel penjelas secara individual mempengaruhi variabel yang dijelaskan secara signifikan. 
2. Jika $t_{\text {hitung }}<t_{\text {tabel, }}$ maka $\mathrm{H}_{1}$ ditolak yang artinya variabel penjelas secara individual tidak mempengaruhi variabel yang dijelaskan secara signifikan.

Uji parsial di peroleh dengan melihat $\mathrm{t}_{\text {tabel }}$ adalah $(\mathrm{n}-\mathrm{k})=84-3=81$ dan pada $\alpha=1 \%$, adalah sebesar $=$ 2,63712 atau 2,64

Berdasarkan Tabel 6 diatas dapat dilihat yaitu :

1. Variabel investasi industri kecil formal memiliki nilait $_{\text {hitung }}>t_{\text {tabel }}$ atau 3.92>2.64, maka tolak H0 dan terima $\mathrm{H}_{1}$, artinya investasi industri kecil formalberpengaruh secara positif terhadap produk domestik regional bruto di Kabupaten Aceh Utara. Hal ini juga dapat dilihat dari probabilitas $0.0002<0.01$.

2. Selanjutnya variabelinvestasi industri kecil non formal memiliki nilai $t_{\text {hitung }}>t_{\text {tabel }}$ atau $-6.78<-2.64$, maka tolak $\mathrm{H} 0$ dan terima $\mathrm{H}_{2}$, artinya investasi industri kecil non formal berpengaruh secara negatif dan signifikan terhadap produk domestik regional bruto di Kabupaten Aceh Utara. Hal ini juga bisa dilihat dari probabilitas $0.0000<0.01$.

\section{Pengujian Simultan (Uji F)}

Uji F dilakukan untuk melihat pengaruh variabel bebas terhadap variabel terikat secara bersama-sama dengan membandingkan antara $F_{\text {hitung }}$ dengan $F_{\text {tabel, }}$ apabila $F_{\text {hitung }}>$ $\mathrm{F}_{\text {tabel, }}$ dengan cara df $(\mathrm{k}-1)(\mathrm{n}-\mathrm{k})=(3-1)(84-3)=(2)(81)=$ 4.88: jadi variabel investasi industri kecil formal dan investasi industri kecil non formal secara bersama-sama berpengaruh terhadap produk domestik regional bruto karena nilai sebesar $1332.33>4,88$. Hal ini juga bisa dilihat dari nilai probabilitas (P-value) sebesar $0.0000<0,01$.

Berdasarkan hasil pengujian yang dilakukan secara serempak atau bersama-sama dari tabel diatas maka dapat dilihat nilai $F_{\text {hitung }}$ sebesar 1332.33 lebih besar dari pada $F_{\text {tabel }}$ yaitu sebesar 4.88 , artinya variabel investasi industri kecil formal dan investasi industri kecil non formal secara bersama-samaberpengaruh terhadap produk domestik regional bruto di Kabupaten Aceh Utara.

\section{Koefisien Determinasi $\left(\mathbf{R}^{2}\right)$ dan Korelasi $(\mathbf{R})$ Koefisien Determinasi $\left(\mathbf{R}^{2}\right)$}

Koefisien determinasi ini mengukur seberapa jauh kemampuan model dalam menerangkan variasi variabel dependen (uji goodness of fit).Koefisien ini nilainya antara 0 (nol) sampai dengan 1 (satu).Semakin besar nilai koefisien tersebut maka variabel-variabel independen lebih mampu menjelaskan variasi variabel dependen. Nilai koefisien determinasi merupakan suatu ukuran yang menunjukkan besar sumbangan dari variabel independen terhadap variabel dependen, atau dengan kata lain koefisien determinasi mengukur variasi turunan $\mathrm{Y}$ yang diterangkan oleh pengaruh linier X. Bila nilai koefisien determinasi yang diberi simbol $\mathrm{R}^{2}$ mendekati angka 1 maka variabel independen makin mendekati hubungan dengan variabel dependen, sehingga dapat dikatakan bahwa pengaruh model tersebut dapat dibenarkan (Gujarati, 2009).

Dari hasil pengolahan data R.Squared sebesar 0.9847 jadi besarnya pengaruh variabel investasi industri kecil formal dan investasi industri kecil non formal terhadap produk domestik regional bruto di Kabupaten Aceh Utara adalah sebesar 0.9847 (98.47\%), dan sisanya 0.0883 (8.83\%) dipengaruhi oleh variabel lain diluar model ini.
Menurut Supranto (2009) analisis korelasi merupakan suatu cara untuk mengetahui kuat atau tidaknya hubungan antara variabel independen (X) dan variabel dependen (Y), apabila dinyatakan dengan fungsi linear dan di ukur dengan suatu nilai yang disebut koefisien korelasi.Berdasarkan hasil pengolahan data pada tabel 4.8 diperoleh nilai korelasi $(R)=\sqrt{R^{2}}=\sqrt{ } 0.985393=0.9927$ Jadi hubungan antara investasi industri kecil formal dan investasi industri kecil non formal sebesar 0.9927 artinya berhubungan sangat erat/sangat kuat secara positif, karena nilai korelasi 0.9927 mendekati positif satu (+1), atau hubungan variabel investasi industri kecil formal dan investasi industri kecil non formal terhadap produk domestik regional bruto sangat kuat secara positif.

\section{Pembahasan}

\section{Pengaruh Investasi Industri Kecil Formal dengan PDRB}

Berdasarkan pengujian secara parsial dapat disimpulkan bahwa variabel investasi industri kecil formal berpengaruh secara signifikan dan positif terhadap produk domestik regional bruto di Kabupaten Aceh Utara. hasil penelitian ini sesuai dengan penelitian yang dilakukan yang pernah dilakukan olehSilalahi (2012) dengan judul Analisis Pengaruh Investasi Dan Tenaga Kerja Terhadap Produk Domestik Regional Bruto (PDRB) Di Sumatera Utara. Analisis data menggunakan regresi data panel dengan menggunakan metode regresi Fixed Effect Model terpilih. Hasil penelitian ini menunjukkan. Persentase investasi domestik, investasi asing dan tenaga kerja berpengaruh positif terhadap produk domestik regional bruto di Sumatera Utara.

\section{PengaruhInvestasi Industri Kecil Non Formal dengan PDRB}

Berdasarkan pengujian secara parsial dapat disimpulkan bahwa variabelinvestasi industri kecil non formal memiliki nilai $t_{\text {hitung }}>t_{\text {tabel }}$ maka tolak $\mathrm{H} 0$ dan terima $\mathrm{H}_{2}$, artinya investasi industri kecil non formal berpengaruh secara positif dan signifikan terhadap produk domestik regional bruto di Kabupaten Aceh Utara. Hal ini juga bisa dilihat dari probabilitas $0.0000<0.05$. Penelitian ini sesuai dengan penelitian yang pernah dilakukan oleh Salim (2008) dengan judul Pengaruh Investasi dan Tenaga Kerja Terhadap PDRB Provinsi Papua. Menggunakan jenis penelitian kuantitatif dengan data sekunder analisa regresi linier berganda. Hasil Penelitian menunjukkan bahwa investasi berpengaruh positif dan signifikan terhadap Pendapatan Domestik Regional Bruto (PDRB) pada Pemerintah Provinsi Papua, dan tenaga kerja berpengaruh positif dan signifikan terhadap Pendapatan Domestik Regional Bruto (PDRB) pada Pemerintah Provinsi Papua.

\section{PENUTUP}

\section{Kesimpulan}

Berdasarkan hasil penelitian dan pembahasan, maka peneliti mengemukakan kesimpulan sebagai berikut :

1. Hasil penelitian secara parsial menunjukkan bahwa investasi industri kecil formal berpengaruh positif terhadap produk domestik regional bruto di Kabuapaten Aceh Utara. Artinya meningkat investasi industri kecil 
formal akan meningkatkan produk domestik regional bruto di Kabupaten Aceh Utara.

2. Hasil penelitian secara parsial menunjukkan bahwa investasi industri kecil non formal berpengaruh negatif terhadap produk domestik regional bruto di Kabuapaten Aceh Utara. Artinya meningkat investasi industri kecil non formal akan menurunkan produk domestik regional bruto di Kabupaten Aceh Utara.

3. Berdasarkan hasil pengujian yang dilakukan secara serempak atau bersama-sama variabel investasi industri kecil formal dan investasi industri kecil non formal berpengaruh secara simultan terhadap produk domestik regional bruto di Kabupaten Aceh Utara, dan besarnya pengaruh variabel investasi industri kecil formal dan investasi industri kecil non formal terhadap produk domestik regional bruto di Kabupaten Aceh Utara adalah sebesar 0.9847 (98.47\%), dan sisanya 0.0883 $(8.83 \%)$ dipengaruhi oleh variabel lain diluar model ini.

\section{Saran}

Adapun saran yang dapat diberikan peneliti dalam penelitian ini adalah sebagai berikut :

1. Penelitian selanjutnya dapat dilakukan pada semua kabupaten dan kota diseluruh Indonesia, dengan menggunakan variabel yang berbeda Hal ini bertujuan untuk memiliki cakupan yang lebih luas dan tidak hanya sebagian daerah saja dan hasilnya dapat diketahui oleh publik.

2. Pemerintah Kabupaten Aceh Utara hendaknya dapat memaksimalkan dalam upaya meningkatkan produk domestik regional bruto dan menggali potensi yang ada di kabupaten tersebut agar dapatmenarik investasi yang lebih besar dimasa yang akan datang.

3. Pemerintah perlu melakukan evaluasi dalam perkembangan PDRB dan melakukan kerja sama dengan pihak akademisi dan menampung ide-ide kreatif tersebut untuk meningkatkan PDRB dan mencapai kemakmuran Kabupaten Aceh Utara.

\section{KEPUSTAKAAN}

Aulia (2018). Analisis Pengaruh Investasi dan Tenaga Kerja Terhadap Pertumbuhan PDRB Sektor Industri Pengolahan di D. I Yogyakarta. Jurnal Ekonomi Pembangunan. Vol 1, No.2

BPS Aceh Utara (2010) Laporan Aceh Utara dalam Angka.

Ginting (2016). Pengaruh Retribusi Daerah dan Laba BUMD Terhadap Produk Domestik Bruto di Sulawei Barat., Jurnal Ekonomi Pembangunan. Hal. 1-64.

Gujarati (2009). Pengaruh Pajak Reklame dan Retribusi Daerah terhadap Produk Domestik Regional Bruto. Jurnal Ekonomi Pembangunan. Vol 2, Nol

Hidayat (2017). Analisis Tingkat Partisipasi Angkatan Kerja (TPAK) dan Investasi terhadap Produk Domestik Regional Brutodi Provinsi Riau. Jurnal Ekonomi. Vol 1 , No 2
Imaniar (2018). Pengaruh Investasi terhadap PDRB di Provinsi Lampung tahun 2012-2016.Jurnal Ekonomi Pembangunan. Vol 1, No.1

Indrajaya, I. G. B. (2016). Pengaruh Modal dan Teanga Kerja Terhadap Produk Domestik Regional Bruto di Denpasar. Jurnal Ekonomi. Vol 2, No 2

Lesmana (2014). Pengaruh Produksi dan Investasi TerhadapProduk Domestik Regional Bruto di Jawa Barat. Hal 1-8

Mahasiswa (2018). Analisis Pengaruh Investasi dan Tenaga Kerja Terhadap Pertumbuhan PDRB Sektor Industri Pengolahan di D. I Yogyakarta ( Tahun 1996-2016 ).

Mauliansyah (2017). Pengaruh Investasi dan Belanja Pemerintah terhadap Produk Domestik Regional Bruto di Provinsi Aceh. Jurnal Ekonomi Pembangunan. Vol 1, No.1

Mukhtar(2015). Dampak Industri Kecil dan Menengah pada Kesempatan Kerja dan Pendapatan per Kapita.

Mulyadi (2001). Dampak Investasi Terhadap Produk Domestik Regional Bruto di Indonesia.

Suindyah (2011). Pengaruh Investasi, tenaga Kerja dan Pengeluaran Pemerintah Terhadap Pertumbuhan Ekonomi di Propinsi Jawa Timur. Jurnal Ekonomi, 15(4), 477-500.

Sugiona (2014). Pengaruh Investasi, Tenaga Kerja dan Infrastruktur Listrik Terhadap Produksi Sektor Konstruksi Antar Provinsi di Pulau Jawa Tahun 2009-2014, 1-64.

Rizky (2015).Pengaruh Pajak dan Retribusi Daerah Terhadap Produk Domestik Regioal Bruto.

Sukirno (2007). Pengaruh Modal dan Bahan bakuTerhadap Produksi Sektor Konstruksi Antar Provinsi di Pulau Jawa.Jurnal Ekonomi. Vol 2, No.1

Sutrisno (2017).Pengaruh Penerimaan Pajak Reklame Dan Pajak Restoran Terhadap Produk Domestik Regioal Bruto ( Pada Suku Dinas Pendapatan Daerah Jakarta Barat II ) 1429 H / 2008 M. (2008).

Supriono (1987)Pengaruh Investasi, Tenaga Kerja dan Modal Terhadap PDRB di Jawa Timur. Jurnal Ekonomi. Vol 2, No.1

Salim(2008).Investasi dan Jumlah Tenga Kerja terhadap PDRB Propinsi Papua tahun 2006- 2010. Vol 2, No.2

Saparuddin (2011). Dampak Industri Kecil dan Menengah pada Kesempatan Kerja dan Pendapatan per Kapita. Jurnal Ekonomi Pembangunan. Vol.2, No. 2

Silalahi (2012). Analisis pengaruh Produk Domestik Regional Bruto Tingkat Investasi dan Tingkat 
Angkatan Kerja terhadap Tingkat Kemiskinan di Sumatera Utara. Jurnal Ekonomi. Vol 1, No 1.

Supranto (2009).Pengaruh Investasi dan BUMN terhadap Produk Domestik Regional Bruto di Jawa Tengah. Jurnal Ekonomi Pembangunan. Vol. 2, No. 2.

Wahyuningsih (2014)Pengaruh Investasi dan Tenaga Kerja Terhadap PDRB di Jawa Timur. Jurnal Ekonomi. Vol 1, No 1

Wiwoho (2018). Analisis Pengaruh Produk Domestik Regional Bruto dan Kabupaten Nagan Raya. Jurnal Ekonomi Pembangunan. Vol 2, No.1. 